\title{
Effects of row spacing and planting density of forage sorghum on dry matter yield, morphologic parameters, nutritive value, and predicted milk yield of dairy cows
}

Efeitos do espaçamento entre linhas e da densidade de plantio do sorgo forrageiro sobre a produção

de matéria seca, parâmetros morfológicos, valor nutritivo e produção prevista de leite de vacas

leiteiras

Efectos del espaciamiento entre hileras y la densidad de siembra del sorgo forrajero sobre la producción de materia seca, parámetros morfológicos, valor nutricional y producción de leche

prevista de las vacas lecheras

Received: 08/12/2021 | Reviewed: 08/17/2021 | Accept: 08/19/2021 | Published: 08/22/2021

\author{
Magno Daniel Porfirio \\ ORCID: https://orcid.org/0000-0002-0755-0254 \\ State University of the West of Paraná, Brazil \\ E-mail: magnoporfirio@gmail.com \\ Marcela Abbado Neres \\ ORCID: https://orcid.org/0000-0003-3221-4030 \\ State University of the West of Paraná, Brazil \\ E-mail: mabaneres@gmail.com \\ Claudia Anete Führ \\ ORCID: https://orcid.org/0000-0002-5630-9942 \\ State University of the West of Paraná, Brazil \\ E-mail: furhca@gmail.com \\ Thiago Henrique da Silva \\ ORCID: https://orcid.org/0000-0002-0028-1127 \\ University of Sao Paulo, Brazil \\ E-mail: silvath@usp.br \\ Iuli Caetano da Silva Brandão Guimarães \\ ORCID: https://orcid.org/0000-0003-1375-1148 \\ University of Sao Paulo, Brazil \\ E-mail: iulivet3@gmail.com
}

\begin{abstract}
This study was undertaken to evaluate the effects of different row spacings and planting populations on dry matter yield, nutritive value, and predicted milk yield of BRS 658 forage sorghum hybrid growing in Brazilian conditions. A late relative maturity forage sorghum [Sorghum bicolor (L.) Moench; $110 \mathrm{~d}-115 \mathrm{~d}$ to soft dough stage; BRS $658-$ Embrapa] was planted at 3 row spacing $(0.5,1.0$ and $1.5 \mathrm{~m})$ and at 3 planting population $\left(50 \times 10^{3}, 100 \times 10^{3}\right.$, and 150 x $10^{3}$ plants.ha $\left.{ }^{-1}\right)$. Treatments were arranged in a randomized complete block design in a 3 x 3 factorial arrangement, using 4 replicate plots per row spacing x plant population combination. At harvest, weights of whole-plant sorghum forage were obtained to calculate DM yields. Chemical composition was assessed by performing wet chemistry analysis. Plant height, stem diameter, and harvest were performed 110 days after sowing (DAS). Estimated milk yield per unit of forage and per hectare were calculated using Milk2006. Summative equations were used to predict TDN and $\mathrm{NE}_{\mathrm{L}}$. Yield of wet and DM forage sorghum exhibited a negative quadratic response as row spacing increased, reaching the maximum yield response at row spacing of $1.23 \mathrm{~m}$ and $1.22 \mathrm{~m}$, respectively. In addition, negative linear effect was detected for both wet and DM sorghum forage yield as planting density increased. Regarding agronomic measurements, sorghum height exhibited a negative linear pattern as plant density increased. Otherwise, stem diameter increased as planting density increased. Whole-plant sorghum forage DM content decreased linearly with increasing planting density. Conversely, ashes increased linearly as planting density increased. Neutral detergent insoluble protein exhibited a positive quadratic effect with increasing planting density, reaching the minimum value when planting density was $104.2 \times 10^{3}$ plants.ha ${ }^{-1}$. Finally, a negative quadratic effect for predicted milk yield per hectare was also observed with increasing row spacing, whereas the maximum milk yield per hectare value was detected when row spacing was $1.20 \mathrm{~m}$. In conclusion, taking into account a subtropical climate, the ideal row spacing and planting density recommendation for a high yield and nutritional quality sorghum forage are $1.2 \mathrm{~m}$ and $104 \times 10^{3}$ plants.ha ${ }^{-1}$, respectively.
\end{abstract}

Keywords: Canopy architecture; Chemical composition; Management; Ruminant nutrition. 


\section{Resumo}

Este estudo foi realizado para avaliar os efeitos de diferentes espaçamentos entre linhas e populações de plantio sobre a produção de matéria seca, valor nutritivo e produção de leite prevista do híbrido de sorgo forrageiro BRS 658 em condições brasileiras. Sorgo forrageiro de maturidade relativa tardia [Sorghum bicolor (L.) Moench; 110d-115d para o estágio de massa macia; BRS 658 - Embrapa] foi plantado com 3 espaçamentos entre linhas (0,5; 1,0 e 1,5 m) e com 3 populações de plantio $\left(50 \times 10^{3}, 100 \times 10^{3}\right.$ e $150 \times 10^{3}$ plantas.ha $\left.^{-1}\right)$. Os tratamentos foram arranjados em um delineamento de blocos ao acaso em um arranjo fatorial $3 \times 3$, usando 4 parcelas repetidas por espaçamento entre linhas x combinação de população de plantas. Na colheita, foram obtidos pesos de plantas forrageiras de sorgo para cálculo da produtividade de matéria seca (MS). A composição química foi avaliada através da realização de análise química convencional. Altura da planta, diâmetro do caule e colheita foram realizados 110 dias após a semeadura (DAS). A produção estimada de leite por unidade de forragem e por hectare foi calculada usando a planilha Milk2006. Equações foram usadas para prever o NDT e o $\mathrm{EL}_{\mathrm{L}}$. A produtividade do sorgo forrageiro úmido e MS apresentou resposta quadrática negativa, com o aumento do espaçamento entre fileiras atingindo a resposta máxima de produção nos espaçamentos de $1,23 \mathrm{~m}$ e 1,22 m, respectivamente. Além disso, foi detectado efeito linear negativo para a produtividade de forragem de sorgo em matéria original e MS com o aumento da densidade de plantio. Em relação às medidas agronômicas, a altura do sorgo exibiu um padrão linear negativo com o aumento da densidade de plantas. Por outro lado, o diâmetro do caule aumentou com o aumento da densidade de plantio. O teor de MS da forragem de sorgo de planta inteira diminuiu linearmente com o aumento da densidade de plantio. Contrariamente, as cinzas aumentaram linearmente com o aumento da densidade de plantio. A proteína insolúvel em detergente neutro apresentou efeito quadrático positivo com o aumento da densidade de plantio, atingindo o valor mínimo quando a densidade de plantio foi de $104,2 \times 10^{3}$ plantas.ha ${ }^{-1}$. Finalmente, um efeito quadrático negativo para a produção prevista de leite por hectare também foi observado com o aumento do espaçamento entre linhas, enquanto o valor máximo da produção de leite por hectare foi detectado quando o espaçamento entre linhas foi de 1,20 m. Em conclusão, considerando um clima subtropical, o espaçamento ideal e a recomendação de densidade de plantio para uma forragem de sorgo de alta produtividade e qualidade nutricional são $1,20 \mathrm{~m} \mathrm{e} 104$ x $10^{3}$ plantas.ha $^{-1}$, respectivamente.

Palavras-chave: Arquitetura do dossel; Composição química; Manejo; Nutrição de ruminantes.

\section{Resumen}

Este estudio tuvo como objetivo evaluar los efectos de diferentes espaciamientos entre hileras y poblaciones de siembra sobre el rendimiento de materia seca, el valor nutricional y la producción de leche prevista del híbrido de sorgo forrajero BRS 658 en las condiciones brasileñas. Sorgo forrajero de madurez relativa tardía [Sorghum bicolor (L.) Moench; 110d-115d para la etapa de masa blanda; BRS 658 - Embrapa] se sembró con 3 espaciamientos entre hileras $(0,5 ; 1,0$ y $1,5 \mathrm{~m})$ y con 3 poblaciones de siembra $\left(50\right.$ x $10^{3}, 100$ x $10^{3}$ y 150 x $10^{3}$ plantas.ha $\left.^{-1}\right)$. Los tratamientos se organizaron en un diseño de bloques al azar en un arreglo factorial de $3 \times 3$, utilizando 4 parcelas repetidas por combinación de espaciado entre filas x población de plantas. En la cosecha se obtuvieron los pesos de las plantas forrajeras de sorgo para calcular el rendimiento de materia seca (MS). La composición química se evaluó mediante la realización de un análisis químico convencional. La altura de la planta, el diámetro del tallo y la cosecha se realizaron 110 días después de la siembra (DAS). La producción de leche estimada por unidad de forraje y por hectárea se calculó utilizando la hoja de cálculo Milk2006. Se utilizaron ecuaciones sumativas para predecir NDT y $\mathrm{EL}_{\mathrm{L}}$. La productividad del sorgo forrajero húmedo y la MS mostró una respuesta cuadrática negativa, con el aumento en el espaciamiento de las hileras alcanzando la respuesta máxima de rendimiento a espaciamientos de $1,23 \mathrm{~m}$ y 1,22 $\mathrm{m}$, respectivamente. Además, se detectó un efecto lineal negativo para el rendimiento de forraje de sorgo en materia original y MS al aumentar la densidad de siembra. En cuanto a las medidas agronómicas, la altura del sorgo mostró un patrón lineal negativo con el aumento de la densidad de plantas. Por otro lado, el diámetro del tallo aumentó al aumentar la densidad de siembra. El contenido de MS del forraje de sorgo de toda la planta disminuyó linealmente con el aumento de la densidad de siembra. Por el contrario, la ceniza aumentó linealmente con el aumento de la densidad de plantación. La proteína neutra insoluble en detergente mostró un efecto cuadrático positivo al aumentar la densidad de siembra, alcanzando el valor mínimo cuando la densidad de siembra fue de $104,2 \times 10^{3}$ plantas.ha $^{-1}$. Finalmente, también se observó un efecto cuadrático negativo para la producción de leche predicha por hectárea con el aumento del espaciamiento entre hileras, mientras que el valor máximo de producción de leche por hectárea se detectó cuando el espaciamiento entre hileras era de 1,20 m. En conclusión, considerando un clima subtropical, el espaciamiento ideal y la recomendación de densidad de siembra para un forraje de sorgo con alto rendimiento y calidad nutricional son $1,20 \mathrm{~m}$ y $104 \times 10^{3}$ plantas.ha $^{-1}$, respectivamente.

Palabras clave: Arquitectura del dossel; Composición química; Manejo; Nutrición de rumiantes.

\section{Introduction}

The wide adaptability of sorghum [Sorghum bicolor (L.) Moench] to drought and warm environments has highlighted it as a great alternative to corn (Zea mays L.) in ruminant nutrition (Getachew et al., 2016). Through its less transpiration ratios 
(Howell et al., 2008) and slower leaf/stalk wilting, sorghum requires 25\% less water compared to corn plants (Martin et al., 1976). Additionally, sorghum crop thrives in low fertility environments requiring less fertilization and pest control management (Derese et al., 2018; Shoemaker \& Bransby, 2010). Altogether, these factors suggesting that sorghum may be a better crop choice in regions where erratic rainfall and high temperatures are often experienced (Staggenborg et al., 2008). Despite sorghum may maintain a similar yield compared to corn, quality measurements such as lower ADF content and higher digestible DM have favored corn silages compared with sorghum silages (Getachew et al., 2016). However, through its high adaptability, sorghum has a large potential to reduce the effects of forage resource seasonality on livestock in different challenging climates around the world (Danalatos et al., 2009; Marsalis et al., 2010).

Management practices such as row spacing and plant populations play an important role in determining the crop yield efficiency (Fernandez et al., 2012). Narrowing row spacing results in a phytochrome-mediate growth response of narrower leaves, longer stems, and afford lesser root biomass increasing leaf area index and plant biomass (Kasperbauer \& Karlen, 1994). Accordingly, among other effects (Ballaré \& Pierik, 2017), high plant population affects light interception through higher GA-3 oxidase expression in leaf collar tissue, which increases synthesis of gibberellin stimulating internode elongation (Yu et al., 2021). Thus, reduced row spacing coupled to increased plant population may affect plant canopy architecture reducing weed competition and, since longer stems are correlated with high biomass yield, all these biological responses may increase crop yield.

Crop design may also affect the nutritive value of whole-plant sorghum forage. McCary et al. (2020) detected a positive linear response in DM content and tendency of a positive linear response in NDF content coupled to a negative linear response in NDF digestibility as sorghum plant density increasing from 148,000 to 346,000 seeds/ha. All these chemicalnutritional modification leaded to a tendency of negative linear response in milk yield efficiency (kg/kg of DM) as plant density increased. However, these authors did not detect differences on forage yield, which provided similar milk yield per area (kg/ha) among agronomic managements. Carmi et al., 2006 and Jahanzad et al. (2013) reported that sorghum plants may be able to compensate for adjustments in seeding rates due to increased plant tillering as plant density decreases. It may maintain biomass yield similar among different plant populations. Otherwise, (Marsalis et al., 2010) did not detect differences in crop yield and nutritive value of corn, forage sorghum, and BMR forage sorghum with different plant populations.

Once the information regarding sorghum seeding rates should be assessed continually due to differences and advancements in hybrid genetics and responses to different locations, this study was undertaken to evaluate the effects of different row spacings $(0.5,1.0$, and $1.5 \mathrm{~m})$ and planting populations $\left(50 \times 10^{3}, 100 \times 10^{3}, 150 \times 10^{3}\right.$ plants.ha $\left.^{-1}\right)$ on dry matter yield, nutritive value, and predicted milk yield of BRS 658 forage sorghum hybrid growing in Brazilian conditions. These findings offer insights into crop architecture management of sorghum forage cultivated in subtropical conditions.

\section{Methodology}

The methodologic approach herein used may be classified as a quantitative method. A quantitative or numerical data is collected due to the use of measurements of quantities, which is obtained through metrology (numbers with their respective units; Yin, 2015).

\subsection{Experimental site}

The study was carried out at the experimental field of the State University of the West of Paraná (UNIOESTE) Research Farm: 2431'55', S, 5401'05', W; altitude 396 m), located in Western Paraná, Marechal Cândido Rondon, PR, Brazil. The study was carried out from October, 2017 to January, 2018. The area has an arid to humid mesothermal (subtropical) climate (type Cfa according to Köppen) with 30-year average annual precipitation of 1752 mm, annual maximum 
average temperature of $27.3^{\circ} \mathrm{C}$ and minimum average temperature of $17.8^{\circ} \mathrm{C}$. The experiment was conducted on a eutrophic red latosol (Oxisol). Prior to seeding, soil samples from each plot were taken from the top $20 \mathrm{~cm}$ of soil to test its background nutritional level. The chemical properties of soil were: $\mathrm{pH}\left(\mathrm{CaCl}_{2}\right)=5.9 ; \mathrm{P}($ Mehlich $)=25.5 \mathrm{mg} \cdot \mathrm{dm}^{-3} ; \mathrm{K}($ Mehlich $)=0.7$ $\operatorname{cmol}_{\mathrm{c}} \cdot \mathrm{dm}^{-3} ; \mathrm{Ca}^{++}\left(\mathrm{KCl} 1 \mathrm{~mol} \cdot \mathrm{L}^{-1}\right)=4.4 \mathrm{cmol}_{\mathrm{c}} \cdot \mathrm{dm}^{-3} ; \mathrm{Mg}^{++}\left(\mathrm{KCl} 1 \mathrm{~mol} \cdot \mathrm{L}^{-1}\right)=3.1 \mathrm{cmol}_{\mathrm{c}} \cdot \mathrm{dm}^{-3} ; \mathrm{Al}^{+++}\left(\mathrm{KCl} 1 \mathrm{~mol} \cdot \mathrm{L}^{-1}\right)=0.0$ cmol $_{c} \cdot \mathrm{dm}^{-3} ; \mathrm{H}+\mathrm{Al}(\mathrm{pH} 7,5)=4.96 \mathrm{cmol}_{\mathrm{c}} \cdot \mathrm{dm}^{-3} ;$ Base saturation $=8.15 \mathrm{cmol}_{\mathrm{c}} \cdot \mathrm{dm}^{-3} ;$ Cation-exchange capacity $=13.1 \mathrm{cmol}_{\mathrm{c}} \cdot \mathrm{dm}^{-3}$; Saturation point $=62.2 \%$; Organic matter $=24.6 \mathrm{~g} \cdot \mathrm{dm}^{-3} ; \mathrm{Cu}=6.5 \mathrm{mg} \cdot \mathrm{dm}^{-3} ; \mathrm{Zn}=8.3 \mathrm{mg} \cdot \mathrm{dm}^{-3} ; \mathrm{Mn}=56.0 \mathrm{mg} \cdot \mathrm{dm}^{-3}$, and Fe $=$ $24.5 \mathrm{mg} . \mathrm{dm}^{-3}$. The average daily precipitation and temperature obtained from an automated weather station device, located at the research farm, are presented in Figure 1.

Figure 1. Total precipitation $(\mathrm{mm})$ and maximum/minimum temperature $\left({ }^{\circ} \mathrm{C}\right)$ from October, 2017 to January, 2018, at the State University of Western Paraná (UNIOESTE) Research Farm. Data were obtained from an automated weather station device.

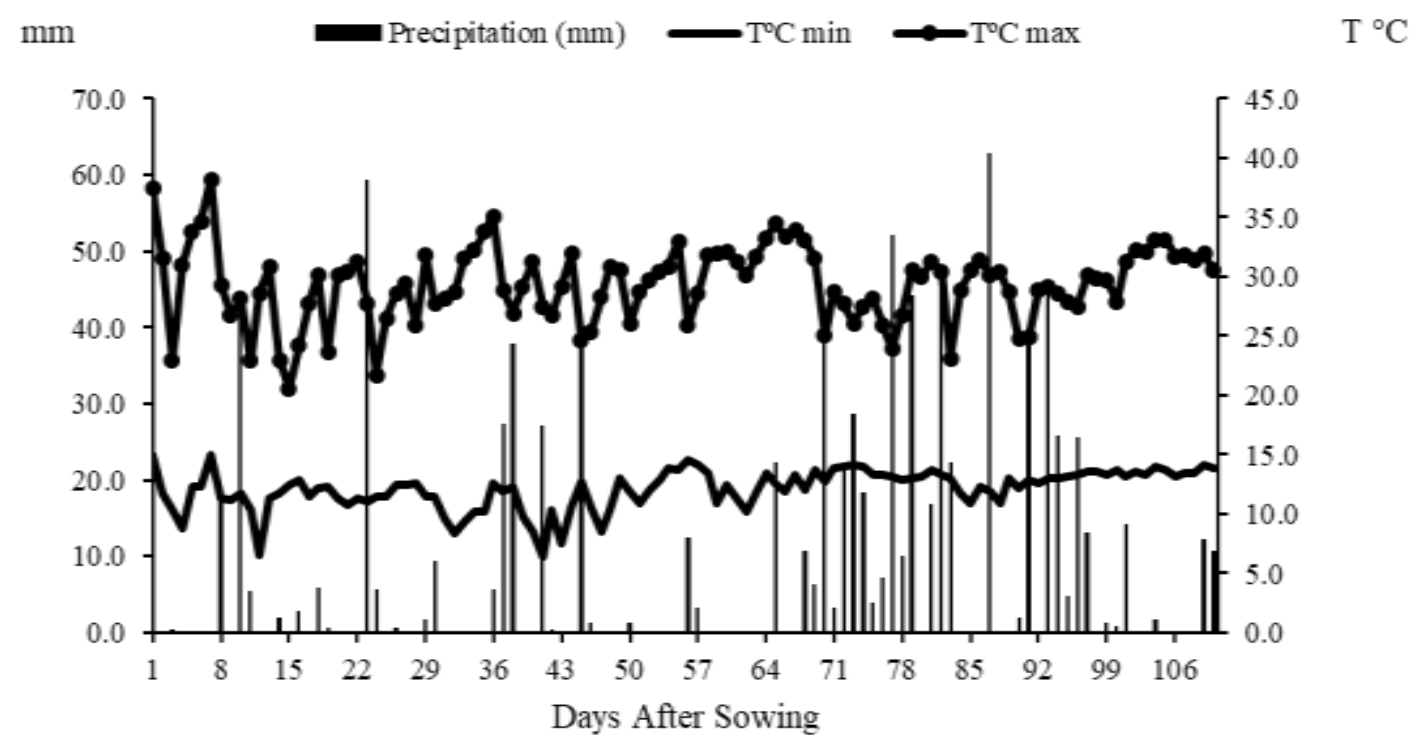

Source: Authors.

\subsection{Experimental design and cultural practices}

A late relative maturity forage sorghum [Sorghum bicolor (L.) Moench; $110 \mathrm{~d}-115 \mathrm{~d}$ to soft dough stage; BRS 658 Embrapa] was planted at 3 row spacing $(0.5,1.0$ and $1.5 \mathrm{~m})$ and at 3 planting population $\left(50 \times 10^{3}, 100 \times 10^{3}\right.$, and $150 \times 10^{3}$ plants.ha ${ }^{-1}$ ). Treatments were arranged in a randomized complete block design in a $3 \times 3$ factorial arrangement, using 4 replicate plots per row spacing x plant population combination. A gap of two meters was considered between adjacent main plots. In the southern Brazil, the typical planting density of forage sorghum used for whole-plant sorghum silage is about 110,000 plants.ha ${ }^{-1}$. Thus, 2 values were selected above and below mean to represent the potential range in planting densities that could be used in that region. Coupled to planting densities, there has been a trend toward reducing row spacing from $0.7 \mathrm{~m}$ (mean) to $0.5 \mathrm{~m}$ in Brazil. Accordingly, we selected 2 values below and above mean to represent the row spacing range used. On October 1 $1^{\text {th }}$, 2017, after conventional seedbed management, a manual 1-row planter (Earthway, 1001-B) was used to plant sorghum at a depth of $5 \mathrm{~cm}$. Each plot consisted of $6 \mathrm{~m}$ (length) $\times 5 \mathrm{~m}$ (width) performing a total area of $30 \mathrm{~m}^{2}$ per plot. Thinning was applied when plants were at 4 leaf-stage to reach the considered plant population at each plant density, where deemed necessary. Fertilizer rate was maintained according to soil test recommendations [at sowing: 30, 45, $45 \mathrm{~kg}$ of N, P, and $\mathrm{K}$ per hectare, respectively; and 35 days after sowing (DAS): 20, 40, $40 \mathrm{~kg}$ of N, P, and K per hectare, respectively]. Plots were 
manually weeded twice, once 15 days after planting and the second time when plants were $30 \mathrm{~cm}$ in height. Seed treatment was performed using the insecticide fipronil plus the fungicides plyraclorstrobin and thiophanate-metyl (100 mL. $\mathrm{kg}^{-1}$ of seeds). Prophylactic pest managements were performed at 21 DAS and at 40 DAS using the insecticide Lufenuron $\left(150 \mathrm{~mL}^{-h a^{-1}}\right)$.

\subsection{Measurements and chemical-nutritional analysis}

Plant height, stem diameter, and harvest were performed on January $30^{\text {th }}, 2018$ (110 DAS). The plant height and stem diameter were assessed based on the average height of 10 randomly selected plants per plot, not considering the edge plants. Plant height was assessed by a calibrated metric tape accounting the distance from the soil surface up to the top of the panicle. In addition, stem diameter was assessed using a digital pachymeter $5 \mathrm{~cm}$ above the ground.

At harvest, the whole plots were hand cut, leaving $10 \mathrm{~cm}$ of stubble in a $2-\mathrm{m}$ continuous section. Thereafter, the sorghum plants were transported to the laboratory, where they were immediately processed with a single-row silage chopper (Nogueira $^{\mathrm{TM}}$, model EM-9F3B, Itapira, SP, Brazil) and placed in a sterile polyvinyl chloride (PVC) plastic bucket. Individual buckets containing whole-plant sorghum forage were weighed and homogenized, and a 500-g sample was taken to measure DM content to calculate DM yield ( $\left.\mathrm{kg} \cdot \mathrm{ha}^{-1}\right)$.

The samples were dried in a forced air oven at $55^{\circ} \mathrm{C}$ for $72 \mathrm{~h}$ and ground in 1-mm screen Willey mill (MA340, Marconi, Piracicaba, SP, Brazil). Dry matter (DM, AOAC 950.15), ether extract (EE, AOAC 920.39) and total N (AOAC, 984.13) contents were analyzed in all samples according to the methods described by (AOAC, 2000). Organic matter (OM) was determined by the difference between DM and ash content. Neutral detergent insoluble protein (NDIP) was determined according to (Licitra et al., 1996). The NDF, ADF and lignin contents were assessed according to Van Soest et al. (1991) using a fiber analyzer (TE-149, Tecnal Equipment for Laboratory Inc., Piracicaba, SP, Brazil). In addition, the NDF samples were treated with amylase and sodium sulfite. Afterwards, the NDF samples were corrected for ashes to obtains the aNDFom (Mertens et al., 2002). Hemicellulose and cellulose content were obtained by the difference between aNDFom and ADF and also between $\mathrm{ADF}$ and lignin, respectively. Additionally, TDN and $\mathrm{NE}_{\mathrm{L}}$ were estimated by forage or silage chemical composition as stated in NRC (2001), considering a cow eating at a $3 \times$ maintenance level. Predicted milk yields per unit of forage yield ( $\mathrm{kg}$ of milk/kg of forage) or per hectare ( $\mathrm{kg}$ of milk/ha) were estimated based on the equations of Milk2006 (Shaver et al., 2006).

In vitro dry-matter digestibility and IVNDFD were determined in conformance with Tilley and Terry (1963). Filter bags (F-57; $50 \times 55$ mm; ANKOM Technology Corporation, Macedon, NY, USA) were identified and weighed. In the formula below, the bag was considered the inoculum without sample. Approximately $0.5 \mathrm{~g}$ of forage samples previously oven-dried and ground were weighed and inserted into filter bags in duplicates. These bags were put into test tubes. Into test tubes, $40 \mathrm{ml}$ of McDougall solution (artificial saliva) were added to $10 \mathrm{ml}$ of rumen inoculum from 3 different steers that had been kept at pasture grazing Brachiaria decumbens and then supplemented with $3.0 \mathrm{~kg}$ of maize silage (DM basis) and ad libitum mineral salt. Tubes were sealed with rubber corks containing a Bunsen gas release valve, immediately after flushing out with $\mathrm{CO} 2$, and incubated in oven for $48 \mathrm{~h}$ under controlled temperature $\left(39^{\circ} \mathrm{C}\right)$. They were agitated a minimum of 3 times during fermentation. The second IVDMD phase occurred after discarding the liquid solution. A pepsin solution (1:10.000) at $0.2 \%$ (50 $\mathrm{ml}$ ) was added to each tube, followed by agitation at $39^{\circ} \mathrm{C}$ for another $48 \mathrm{hr}$. After washing, drying and weighing the bags, calculations were performed as the formula below:

$$
\text { IVDMD }=100 \times\left[\frac{[\mathrm{g} \text { DM in sample-(g of residual DM-g of DM of inoculum without sample) }]}{\mathrm{g} \text { of DM in sample }}\right]
$$


Same procedure was performed in IVOMD and IVNDFD analyses, except that the bags were submitted to aNDFom washing procedures after incubation. Water-soluble carbohydrate was determined according to (Johnson et al., 1964).

Total carbohydrates (TC) were obtained by the following equation: $\mathrm{TC}=100-(\% \mathrm{CP}+\% \mathrm{EE}+\%$ ashes $)$ according to Sniffen et al. (1992). Non-fibrous carbohydrate was determined according to the equation: NFC = CT - aNDFom, Nondigestible carbohydrates was considered the NDF residue after 240h of in vitro incubation [uNDF; Palmonari et al., (2016)]. Thus, potentially digestible carbohydrate (PDC) was determined following the equation: PDC $=$ TC - non-digestible carbohydrates.

\subsection{Statistical analysis}

All statistical analyses were performed in SAS version 9.4 (SAS Institute Inc., Cary, NC). Continuous variables were analyzed by the "Restricted maximum likelihood" ANOVA method for a randomized block design using the MIXED procedure according to the following model:

$$
Y_{i j k l}=\mu+\alpha_{i}+\beta_{j}+\alpha \beta_{i j}+B_{1}+e_{i j k l}
$$

wherein: $\mathrm{Y}_{\mathrm{ijkl}}=$ represents the observation for plot $k$ in a given treatment $i j$ in block $l ; \mu=$ is the intercept; $\alpha_{\mathrm{i}}=$ fixed effect of $i^{\text {th }}$ row spacing $(i=1 \ldots 3) ; \beta_{\mathrm{j}}=$ fixed effect of $j^{\text {th }}$ plant density $(\mathrm{j}=1 \ldots 3) ; \alpha \beta_{\mathrm{ij}}=$ fixed interaction effect of row spacing by plant density; $\mathrm{B}_{1}=$ random effect of $l^{\text {th }}$ block $(1=1 \ldots 4) \approx N\left(0 ; \sigma_{\mathrm{B}}^{2}\right) ; \mathrm{e}_{\mathrm{ijkl}}=$ random error associated with each observation $\approx N\left(0 ; \sigma_{\mathrm{e}}{ }^{2}\right)$. $N=$ Gaussian distribution; $\sigma_{\mathrm{B}}{ }^{2}=$ estimated variance associated with blocks; $\sigma_{\mathrm{e}}{ }^{2}=$ estimated residual variance. Prior to analyses, the normality of the residuals was verified by the Shapiro-Wilk test using the PROC UNIVARIATE command. Studentized residuals greater than +3 or less than -3 were considered "outliers" and excluded from the analysis. The homogeneity of variances was compared using the Levene test. The two factors included in the fixed effect were evaluated using polynomial regression, separating linear and quadratic effect when appropriate $(P<0.05)$. When quadratic effects were significant, the row spacing and/or plant density level at the peak value of the quadratic response was estimated. If the interaction between the factors was present, response-surface approach was conducted using the RSREG procedure. A ridge analysis was also applied to compute the optimal response (maximal or minimal) using RIDGE MAX and/or RIDGE MIN commands. Means were adjusted by LSMEANS statement. Significance level was set at $5 \%(P \leq 0.05)$.

\section{Results}

Effects of row spacing and planting density on whole-plant sorghum forage yield and agronomic measurements are shown in Table 1. Yield of wet and DM forage sorghum exhibited a negative quadratic response as row spacing increased, reaching the maximum yield response at row spacing of $1.23 \mathrm{~m}(\mathrm{P}=0.03)$ and $1.22 \mathrm{~m}(\mathrm{P}=0.03)$, respectively. In addition, negative linear effect was detected for both wet $(\mathrm{P}=0.02)$ and $\mathrm{DM}(\mathrm{P}=0.004)$ sorghum forage yield as planting density increased. Regarding agronomic measurements, sorghum height exhibited a negative linear pattern as plant density increased $(\mathrm{P}=0.003)$. Otherwise, stem diameter increased as planting density increased $(\mathrm{P}<0.0001)$. 
Research, Society and Development, v. 10, n. 11, e36101119374, 2021

(CC BY 4.0) | ISSN 2525-3409 | DOI: http://dx.doi.org/10.33448/rsd-v10i11.19374

Table 1. Effects of row spacing and planting density on wet and DM yield, height, and stem diameter of whole-plant sorghum forage.

\begin{tabular}{|c|c|c|c|c|c|c|c|c|c|c|}
\hline \multirow[b]{2}{*}{ Item } & \multicolumn{3}{|c|}{ Row spacing (m) } & \multicolumn{3}{|c|}{ Density $\left(\mathrm{x} 10^{3}\right.$ plants.ha $\left.{ }^{-1}\right)$} & \multirow[b]{2}{*}{ SEM } & \multicolumn{3}{|c|}{ P-value ${ }^{1}$} \\
\hline & 0.5 & 1.0 & 1.5 & 50 & 100 & 150 & & Row spacing & Density & $\begin{array}{c}\text { Spacing } \\
\text { x Density }\end{array}$ \\
\hline Yield of wet forage $\left(\mathrm{kg} \cdot \mathrm{ha}^{-1}\right)$ & 57,044 & 86,440 & 85,028 & 86,491 & 76,394 & 63,551 & $4,553.8$ & $0.0004_{Q^{2}}^{2}$ & $0.02_{\mathrm{L}}^{3}$ & 0.36 \\
\hline Yield of DM (kg.ha-1) & 14,267 & 22,157 & 21,663 & 22,946 & 19,002 & 15,560 & 1224.1 & $0.0006 \mathrm{Q}^{4}$ & $0.005_{\mathrm{L}}^{5}$ & 0.68 \\
\hline Height $(\mathrm{cm})$ & 291.78 & 299.67 & 291.73 & 303.82 & 292.18 & 287.18 & 2.40 & 0.24 & $0.01_{\mathrm{L}}^{6}$ & 0.51 \\
\hline Stem diameter (mm) & 27.17 & 26.52 & 27.2 & 24.88 & 27.32 & 28.69 & 0.38 & 0.49 & $<0.0001_{\mathrm{L}}^{7}$ & 0.22 \\
\hline
\end{tabular}

${ }^{1} \mathrm{~L}=$ Linear effect, $\mathrm{Q}=$ Quadratic effect;

${ }^{2} \mathrm{Y}=-3156.8( \pm 25519)+151209( \pm 54971) \times$ Spacing $-61612( \pm 27305) \times \operatorname{Spacing}^{2}(\mathrm{P}=0.03 ;$ Maximum value $=1.23 \mathrm{~m}) ; \mathrm{R}^{2} 0.25$;

${ }^{3} \mathrm{Y}=98379( \pm 12199)-228,8( \pm 91.4) \times$ Density $(\mathrm{P}=0.019) ; \mathrm{R}^{2} 0,11$

${ }^{4} \mathrm{Y}=-2007.5( \pm 7062)+40932( \pm 15379) \times$ Spacing $-16768( \pm 7639) \times \operatorname{Spacing}^{2}(\mathrm{P}=0.03$; Maximum value $=1.22 \mathrm{~m}) ; \mathrm{R}^{2} 0.24$

${ }^{5} \mathrm{Y}=26558( \pm 3151)-73.9( \pm 24.1) \times$ Density $(\mathrm{P}=0.004) ; \mathrm{R}^{2} 0.17$

${ }^{6} \mathrm{Y}=311.0( \pm 5.6)-0.16( \pm 0.05) \times$ Density $(\mathrm{P}=0.003) ; \mathrm{R}^{2} 0.20$

${ }^{7} \mathrm{Y}=23.1( \pm 0.76)+0.03( \pm 0.006) \times$ Density $(\mathrm{P}<0.0001) ; \mathrm{R}^{2} 0.47$

Source: Authors.

Effects of row spacing and planting density on whole-plant sorghum forage chemical composition is shown in Table 2. Whole-plant sorghum forage DM content (g.kg ${ }^{-1}$ at time of harvest) decreased linearly $(\mathrm{P}=0.02)$ with increasing planting density. Conversely, ashes increased linearly as planting density increased $(\mathrm{P}<0.003)$ impacting the organic matter content, which decreased linearly $(\mathrm{P}<0.0003$; data not shown). Neutral detergent insoluble protein exhibited a positive quadratic effect $(\mathrm{P}=0.03)$ with increasing planting density, reaching the minimum value when planting density was $104.2 \times 10^{3}$ plants.ha $^{-1}$. A negative quadratic effect for predicted milk yield per hectare was also observed with increasing row spacing $(\mathrm{P}=0.03)$. The maximum milk yield per hectare value was detected when row spacing was $1.20 \mathrm{~m}$.

Table 2. Effects of row spacing and planting density on nutritive value and predicted milk yield of whole-plant sorghum forage (g.kg-1 ${ }^{-1}$ M, unless otherwise stated). 
Research, Society and Development, v. 10, n. 11, e36101119374, 2021

(CC BY 4.0) | ISSN 2525-3409 | DOI: http://dx.doi.org/10.33448/rsd-v10i11.19374

\begin{tabular}{|c|c|c|c|c|c|c|c|c|c|c|}
\hline \multirow[b]{2}{*}{ Item } & \multicolumn{3}{|c|}{ Row spacing (m) } & \multicolumn{3}{|c|}{ Density $\left(\mathrm{x} 10^{3}\right.$ plants.ha $\left.{ }^{-1}\right)$} & \multirow[b]{2}{*}{ SEM } & \multicolumn{3}{|c|}{ P-value ${ }^{5}$} \\
\hline & 0.5 & 1.0 & 1.5 & 50 & 100 & 150 & & Row spacing & Density & $\begin{array}{c}\text { Spacing x } \\
\text { Density }\end{array}$ \\
\hline Dry matter $\left(\mathrm{g} \cdot \mathrm{kg}^{-1}\right)$ & 248.3 & 256.6 & 253.4 & 264.5 & 246.8 & 247.1 & 3.13 & 0.52 & $0.03_{\mathrm{L}}{ }^{6}$ & 0.57 \\
\hline Ash & 65.9 & 64.9 & 67.6 & 61.1 & 67.0 & 70.3 & 1.35 & 0.63 & $0.01_{\mathrm{L}}^{7}$ & 0.28 \\
\hline Ether extract & 17.4 & 17.7 & 17.6 & 18.6 & 16.5 & 17.5 & 0.51 & 0.97 & 0.28 & 0.52 \\
\hline Crude protein & 70.6 & 68.7 & 69.1 & 68.8 & 72.1 & 67.5 & 1.31 & 0.84 & 0.41 & 0.99 \\
\hline $\operatorname{NDIP}^{1}\left(\mathrm{~g} \cdot \mathrm{kg}^{-1} \mathrm{CP}\right)$ & 478.1 & 488.5 & 491.6 & 510.2 & 461.4 & 486.6 & 10.8 & 0.73 & $0.05_{Q^{8}}$ & 0.06 \\
\hline aNDFom $^{2}$ & 751.4 & 744.8 & 735.2 & 743.5 & 744.5 & 743.5 & 3.87 & 0.22 & 0.99 & 0.15 \\
\hline $\mathrm{ADF}^{3}$ & 493.8 & 478.7 & 492.1 & 478.1 & 490.7 & 495.8 & 5.08 & 0.37 & 0.30 & 0.39 \\
\hline Lignin & 131.0 & 126.5 & 130.2 & 128.3 & 131.1 & 128.4 & 2.07 & 0.65 & 0.84 & 0.42 \\
\hline Cellulose & 174.3 & 170.0 & 177.7 & 173.0 & 176.3 & 172.8 & 2.69 & 0.52 & 0.84 & 0.32 \\
\hline Hemicellulose & 257.6 & 266.0 & 243.0 & 265.3 & 253.7 & 247.6 & 5.43 & 0.24 & 0.42 & 0.83 \\
\hline $\mathrm{NE}_{1}(\text { Mcal.kg-1 })^{4}$ & 1.09 & 1.15 & 1.09 & 1.11 & 1.10 & 1.13 & 0.02 & 0.08 & 0.65 & 0.47 \\
\hline Milk Yield (kg.kg-1 DM) & 891.2 & 984.7 & 888.6 & 912.0 & 906.6 & 945.9 & 32.6 & 0.07 & 0.65 & 0.49 \\
\hline Milk Yield (kg.ha-1) & 12,868 & 21,643 & 20,763 & 21,178 & 17,625 & 16,471 & $2,925.5$ & $0.0011_{Q}{ }^{9}$ & 0.12 & 0.41 \\
\hline
\end{tabular}

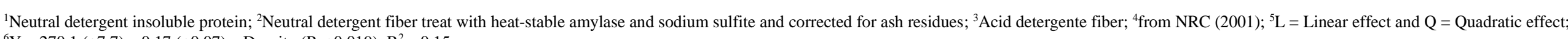

${ }^{6} \mathrm{Y}=270.1( \pm 7.7)-0.17( \pm 0.07) \times$ Density $(\mathrm{P}<0.019) ; \mathrm{R}^{2}=0.15$

$\mathrm{Y}=56.9( \pm 3.2)+0.09( \pm 0.02) \times$ Density $(\mathrm{P}<0.003) ; \mathrm{R}^{2}=0.22$

${ }^{8} \mathrm{Y}=638.4( \pm 70.7)-3.6( \pm 1.5) \times$ Density $+0.01( \pm 0.007) \times$ Density ${ }^{2}\left(\mathrm{P}=0.03 ;\right.$ Minimum value $=104.2 \times 10^{3}$ plants.ha $\left.{ }^{-1}\right) ; \mathrm{R}^{2}=0.11$.

${ }^{9} \mathrm{Y}=-5560.3( \pm 7829)+46511( \pm 16921) \times$ Spacing $-19308( \pm 8373.9) \times \operatorname{Spacing}^{2}(\mathrm{P}=0.03$; Maximum value $=1.20 \mathrm{~m}) ; \mathrm{R}^{2}=0.23$.

Source: Authors

Although there was an impact of row spacing and planting density on chemical composition of forage sorghum in different population arrangements, no differences were detected on nutritional parameters, which included TDN, IVDMD, IVNDFD, IVOMD, and fractions of total carbohydrate (P>0.05; Table 3). 
Research, Society and Development, v. 10, n. 11, e36101119374, 2021

(CC BY 4.0) | ISSN 2525-3409 | DOI: http://dx.doi.org/10.33448/rsd-v10i11.19374

Table 3. Effects of row spacing and planting density on digestibility and carbohydrate fractions of whole-plant sorghum forage.

\begin{tabular}{|c|c|c|c|c|c|c|c|c|c|c|}
\hline \multirow{2}{*}{ Item } & \multicolumn{3}{|c|}{ Row spacing (m) } & \multicolumn{3}{|c|}{ Density (x10 $0^{3}$ plants.ha- $\left.{ }^{1}\right)$} & \multirow[b]{2}{*}{ SEM } & \multicolumn{3}{|c|}{ P-value } \\
\hline & 0.5 & 1.0 & 1.5 & 50 & 100 & 150 & & $\begin{array}{c}\text { Row } \\
\text { spacing }\end{array}$ & Density & $\begin{array}{c}\text { Spacing } \\
\text { x Density }\end{array}$ \\
\hline Total Digestible Nutrients (g. $\left.\mathrm{kg}^{-1} \mathrm{DM}\right)$ & 575.8 & 570.0 & 556.2 & 580.2 & 558.8 & 562.9 & 7.73 & 0.18 & 0.11 & 0.08 \\
\hline $\operatorname{IVDMD}^{1}\left(\mathrm{~g} \cdot \mathrm{kg}^{-1} \mathrm{DM}\right)$ & 412.9 & 423.5 & 441.4 & 408.1 & 440.7 & 428.9 & 14.6 & 0.29 & 0.20 & 0.08 \\
\hline $\operatorname{IVNDFD}^{2}\left(\mathrm{~g} \cdot \mathrm{kg}^{-1} \mathrm{DM}\right)$ & 541.3 & 584.0 & 529.4 & 533.2 & 549.0 & 572.4 & 10.1 & 0.06 & 0.26 & 0.53 \\
\hline $\operatorname{IVOMD}^{3}\left(\mathrm{~g} \cdot \mathrm{kg}^{-1} \mathrm{DM}\right)$ & 585.6 & 574.1 & 552.3 & 588.3 & 556.2 & 567.5 & 8.82 & 0.25 & 0.28 & 0.16 \\
\hline Water-soluble carbohydrate (g. $\left.\mathrm{kg}^{-1} \mathrm{DM}\right)$ & 77.39 & 81.08 & 76.4 & 79.13 & 76.14 & 79.65 & 7.11 & 0.88 & 0.93 & 0.93 \\
\hline Total carbohydrate (g.kg-1 DM) & 846.0 & 848.6 & 845.5 & 851.4 & 844.3 & 844.5 & 3.58 & 0.80 & 0.29 & 0.81 \\
\hline Non-fibrous carbohydrate (g. $\left.\mathrm{kg}^{-1} \mathrm{TC}\right)$ & 149.7 & 162.0 & 170.1 & 166.5 & 156.5 & 158.8 & 9.0 & 0.29 & 0.71 & 0.41 \\
\hline $\mathrm{PDC}^{4}\left(\mathrm{~g} \cdot \mathrm{kg}^{-1} \mathrm{TC}\right)$ & 478.5 & 480.2 & 460.1 & 471.8 & 470.8 & 476.1 & 11.4 & 0.40 & 0.94 & 0.23 \\
\hline Non-digestible carbohydrate (g.kg-1 TC) & 371.8 & 357.8 & 369.8 & 361.7 & 372.7 & 365.1 & 10.6 & 0.60 & 0.75 & 0.52 \\
\hline
\end{tabular}

${ }^{1}$ in vitro dry matter digestibility;

${ }^{2}$ in vitro neutral detergent fiber digestibility;

${ }^{3}$ in vitro organic matter digestibility;

${ }^{4}$ Potentially digestible carbohydrate.

Source: Authors. 


\section{Discussion}

A misinterpretation of crop sorghum arrangement effects on forage sorghum productivity may be performed since published studies have not been designed to investigate the interaction of different row spacings and planting densities. The objectives of this study were to evaluate the effect of row spacing and planting density modulation of sorghum forage crop on fresh and DM yield, morphological parameters, nutritive value, predicted milk yield (per DM and area), and digestibility of sorghum. Overall, the effects of row spacing and plant population density on whole-plant forage yield, height, and stem diameter were meaningful in this study. Additionally, the sorghum plant rearrangement affected some chemical composition parameters and predicted milk yield both per kg of DM and area. Otherwise, no differences were detected in digestibility and carbohydrate fractions of whole-plant forage sorghum among treatments. The meteorological analysis presented in Figure 1 demonstrates that there were high total precipitation and the environmental temperature was greater than $30^{\circ} \mathrm{C}$ and was not lower than $15^{\circ} \mathrm{C}$ for most days. Thus, we may conclude that the climate fits a classical tropical profile. However, as sorghum forage has mainly been sowed during the off-season, the findings herein presented should be interpreted with care.

Sorghum forage DM yield have been shown to have a range of 9 - 22 t.ha' ${ }^{-1}$ (Carmi et al., 2006; Mahmood \& Honermeier, 2012; Miron et al., 2005). In the present study, wet and DM yield of forage sorghum were quadratically affected as row spacing increased. The maximum value for whole-plant sorghum forage wet yield was observed with a row spacing of $1.23 \mathrm{~m}$. Similarly, greater yield of DM was detected at $1.22 \mathrm{~m}$ of row spacing. Narrower row spacings improves light interception (Steiner, 1986), decreases intra-row competition between plants (De Bruin \& Pedersen, 2008), and can also improve weed control by increasing crop competitiveness and reducing light transmittance to the soil (Fernandez et al., 2012). Hence, it would be expected that narrower row spacings would improve forage yield. Snider et al. (2012) evaluated the effect of 3 different row spacings $(0.19,0.38$, and $0.79 \mathrm{~m})$ on biomass production of sorghum. The authors detected higher forage yield in narrower row spacing for all locations and years studied. In our study, conversely, we detected lower forage yield at narrowest row spacing $(0.5 \mathrm{~cm})$ compared to other treatments. However, herein we investigated 3 wider row spacings compared to those usually studied, which preclude a precise comparison of the sorghum forage yield responses among studies. In addition, sorghum yield responses appear to be dependent upon location and cultivar (Snider et al., 2012). Furthermore, row spacing may affect lodging intensity, influencing sorghum forage yield. Mahmood and Honermeier (2012) studying different sorghum cultivar with contrasting row spacing, detected $15 \%$ percentage points more lodging intensity to narrower row spacing compared to wider row spacing. The authors hypothesized that the greater proportion of plant stand in wider row spacing compensated for differences in plant distribution that could affect intra-row competition.

Parallelly to wet and DM yield, plant height decreased linearly with planting density. Several shade avoidance response-signaling pathways, such as phytocromes, cryptochromes, phototropins, UV-B photoreceptors, and hormones have been reported to monitor the environmental light and mediate responses to nearby plants (Ballaré \& Pierik, 2017). Therefore, high planting density, which increase canopy shading, is expected to induce stem elongation, increasing canopy height helping plants outcompete neighboring plants for sunlight. Hence, because increased plant height is correlated with elevated biomass yield, a higher forage yield in higher planting density would be expected. However, canopy shading reduces branching (tillering) and induces early onset of leaf senescence, flowering and seed dormancy, which may decrease forage yield, as reported in this study (Yu et al., 2021). Additionally, high planting density can reduce plant individual water availability, which may lead to water deficiency, followed by yield decrease (Berenguer \& Faci, 2001; Carmi et al., 2006).

Inversely to plant height response, stem diameter increased linearly with planting density, with values ranging from 24.88 to $28.69 \mathrm{~mm}$ from lower to higher planting density, respectively. Opposite response was detected by Tang et al. (2018) and $\mathrm{Yu}$ et al. (2021). The latest authors, found smaller internode diameter for high planting density compared to low planting density, showing the average stem diameter from 9 phytomers along the length of sorghum plants. However, these authors 
reported no differences in internode diameter measurements from those located in the lowest part of the plant. It shows that measuring height of a specific internode may influence the trials' stem diameter outcomes. In this study, we evaluated the stem diameter at $5 \mathrm{~cm}$ up from the ground (bottom third of plants), so this methodology divergency may explain the contrary findings among studies.

Whole-plant sorghum forage DM concentration decreased linearly as planting density increased, with values ranging from 264.5 g. $\mathrm{kg}^{-1}$ at lower planting density to $247.1 \mathrm{~g} . \mathrm{kg}^{-1}$ at higher planting density. Low planting density allows higher soil temperature by increased light intensity, elevating water losses from the soil surface (Stickler \& Laude, 1960). Corroborating, Moreira et al. (2015), studying the impact of planting density on soybean physiology, detected reduced stomatal conductance and transpiration rate in high planting densities compared to lower planting density. Therefore, in this study, we believe that this phenomenon may have decreased the DM concentration as planting density increased, decreasing DM concentration of the whole-plant. On the other hand, McCary et al. (2020) detected increased DM concentration as planting density increased, in which the authors believe be through increased tillering at lower planting densities reducing DM concentration of the wholeplant sorghum forage.

Ash concentration decreased linearly as planting density increased. Corroborating, Moreira et al. (2015) detected higher N, P, K, Ca, S, and Cu concentration in leaves of soybean at R5 growth stage as planting density increased from 222 to $667 \times 10^{3}$ plants.ha $^{-1}$. The authors justified these findings considering the lower individual shoot dry weight observed in higher plant densities, which can reduce the nutrient concentration in the plant (Steiner, 1986). Likewise, this biological effect may explain the linear decrease of ash concentration as sorghum forage planting density increased in this study.

Neutral detergent insoluble protein is the main protein fraction in several plant forage sources. The NDICP is slowly degraded in the rumen and, indirectly, can negatively affect the forage energy content (NRC, 2001; Sniffen et al., 1992). In this study, NDIP values was positively quadratically affected, reaching the minimum NDIP concentration at $104.2 \times 10^{3}$ plants.ha $^{-1}$. As mentioned before, lower planting density may allow higher light intensity, which increase the temperature at the bottom part of canopy. In consequence, this higher temperature can increase the NDIP values since it is correlated to higher nitrogenfiber complexation (Johnson et al., 2001). Nevertheless, to date, there is no study reporting the NDIP concentration in sorghum forage under different crop architecture.

Row spacing affected quadratically predicted milk per hectare response, achieving the higher value at $1.20 \mathrm{~m}$ row spacing. Similarly, wet and DM forage yield were higher at 1.23 and $1.22 \mathrm{~m}$ row spacing. As the Milk2006 (Shaver et al., 2006) spreadsheet consider the forage yield potential to predict milk yield per hectare, the result herein presented for milk yield per area only reflected the forage yield response detected among row spacings.

\section{Conclusion}

In conclusion, increasing row spacing from 0.5 to $1.5 \mathrm{~m}$ quadratically increased sorghum forage and milk yield, achieving the highest value for both at $1.2 \mathrm{~m}$ row spacing. Furthermore, forage yield and plant height decreased linearly as planting density increased from $50 \times 10^{3}$ to $150 \times 10^{3}$ plants.ha $^{-1}$. Additionally, increasing planting density linearly increased stem diameter, reduced DM and ash concentration, and affected quadratically NDIP concentration of sorghum forage, achieving the lowest value at $104 \times 10^{3}$ plants.ha $^{-1}$. Summarizing, in similar climate conditions, the ideal row spacing and planting density for a high yield and nutritional quality sorghum forage are $1.2 \mathrm{~m}$ and $104 \times 10^{3}$ plants.ha ${ }^{-1}$, respectively. Notwithstanding, evaluation of sorghum forage responses to differences in planting management and climate condition should be performed regularly to optimize whole-plant sorghum forage production. 


\section{Acknowledgments}

The authors thank the State University of the West of Paraná (UNIOESTE), for providing the facilities and staff necessary for this experiment. Also, the authors express appreciation to the Brazilian funding agency CAPES ("Coordenação de Aperfeiçoamento de Pessoal de Nível Superior”) and CNPq (“Conselho Nacional de Desenvolvimento Científico e Tecnológico") for providing the fellowships.

\section{References}

AOAC. (2000). Official Methods od Analysis - Animal Feed. In Official Methods of Analysis (17th ed.). The Association of Official Analytical Cheimists.

Ballaré, C. L., \& Pierik, R. (2017). The shade-avoidance syndrome: Multiple signals and ecological consequences. Plant Cell and Environment, 40(11), 25302543. https://doi.org/10.1111/pce.12914

Berenguer, M. J., \& Faci, J. M. (2001). Sorghum (Sorghum Bicolor L. Moench) yield compensation processes under different plant densities and variable water supply. European Journal of Agronomy, 15(1), 43-55. https://doi.org/10.1016/S1161-0301(01)00095-8

Carmi, A., Aharoni, Y., Edelstein, M., Umiel, N., Hagiladi, A., Yosef, E., Nikbachat, M., Zenou, A., \& Miron, J. (2006). Effects of irrigation and plant density on yield, composition and in vitro digestibility of a new forage sorghum variety, Tal, at two maturity stages. Animal Feed Science and Technology, 131(1-2), 121-133. https://doi.org/10.1016/j.anifeedsci.2006.02.005

Danalatos, N., Archontoulis, S., \& Tsiboukas, K. (2009). Comparative analysis of sorghum vs corn growing under optimum and under water/nitrogen limited conditions in central Greece. 17th European Biomass Conference and Exhibition, 2(July), 538-544.

De Bruin, J. L., \& Pedersen, P. (2008). Effect of row spacing and seeding rate on soybean yield. Agronomy Journal, 100(3), 704-710. https://doi.org/10.2134/agronj2007.0106

Derese, S. A., Shimelis, H., Laing, M., \& Mengistu, F. (2018). The impact of drought on sorghum production, and farmer's varietal and trait preferences, in the north eastern Ethiopia: implications for breeding. Acta Agriculturae Scandinavica Section B: Soil and Plant Science, 68(5), 424-436. https://doi.org/10.1080/09064710.2017.1418018

Fernandez, C. J., Fromme, D. D., \& Grichar, W. J. (2012). Grain sorghum response to row spacing and plant populations in the Texas Coastal Bend region. International Journal of Agronomy, 2012, 1-6. https://doi.org/10.1155/2012/238634

Getachew, G., Putnam, D. H., De Ben, C. M., \& De Peters, E. J. (2016). Potential of Sorghum as an Alternative to Corn Forage. American Journal of Plant Sciences, 07(07), 1106-1121. https://doi.org/10.4236/ajps.2016.77106

Howell, T. A., Evett, S. R., Tolk, J. A., Copeland, K. S., Colaizzi, P. D., \& Gowda, P. H. (2008). Evapotranspiration of corn and forage sorghum for silage. Environmental and Water Resources Institute World Congress Proceedings.

Jahanzad, E., Jorat, M., Moghadam, H., Sadeghpour, A., Chaichi, M. R., \& Dashtaki, M. (2013). Response of a new and a commonly grown forage sorghum cultivar to limited irrigation and planting density. Agricultural Water Management, 117, 62-69. https://doi.org/10.1016/j.agwat.2012.11.001

Johnson, C. R., Reiling, B. A., Mislevy, P., \& Hall, M. B. (2001). Effects of nitrogen fertilization and harvest date on yield, digestibility, fiber, and protein fractions of tropical grasses. Journal of Animal Science, 79(9), 2439-2448. https://doi.org/10.2527/2001.7992439x

Johnson, R. R., Balwani, T. L., Johnson, L. J., Mcclure, K. E., \& Dehority, B. A. (1964). Corn Plant Maturity. II. Effect on in vitro cellulose digestibility and soluble content. Journal of Animal Science, 25(3), 617-623.

Kasperbauer, M. J., \& Karlen, D. L. (1994). Plant spacing and reflected far-red light effects on phytochrome-regulated photosynthate allocation in corn seedlings. Crop Science, 34(6), 1564-1569. https://doi.org/10.2135/cropsci1994.0011183X003400060027x

Licitra, G., Hernandez, T. M., \& Van Soest, P. J. (1996). Feedbunk management evaluation techniques. Animal Feed Science Technology, 57, $347-358$.

Mahmood, A., \& Honermeier, B. (2012). Chemical composition and methane yield of sorghum cultivars with contrasting row spacing. Field Crops Research, 128, 27-33. https://doi.org/10.1016/j.fcr.2011.12.010

Marsalis, M. A., Angadi, S. V., \& Contreras-Govea, F. E. (2010). Dry matter yield and nutritive value of corn, forage sorghum, and BMR forage sorghum at different plant populations and nitrogen rates. Field Crops Research, 116(1-2), 52-57. https://doi.org/10.1016/j.fcr.2009.11.009

Martin, J. H., Leonard, W. H., \& Stamp, D. . (1976). Principles of Field Crop Production. Macmillan Publishing Co., Inc.

McCary, C. L., Heinzen, C., Paula, E. M., Wallau, M. O., \& Ferraretto, L. F. (2020). SHORT COMMUNICATION: Effects of planting density on nutritive value, dry matter yield, and predicted milk yield of dairy cows from 2 brown midrib forage sorghum hybrids. Applied Animal Science, 36(3), 320-328. https://doi.org/10.15232/aas.2019-01966

Mertens, D. R., Allen, M., Carmany, J., Clegg, J., Davidowicz, A., Drouches, M., Frank, K., Gambin, D., Garkie, M., Gildemeister, B., Jeffress, D., Jeon, C. S., Jones, D., Kaplan, D., Kim, G. N., Kobata, S., Main, D., Moua, X., Paul, B., ... Wolf, M. (2002). Gravimetric determination of amylase-treated neutral detergent fiber in feeds with refluxing in beakers or crucibles: Collaborative study. Journal of AOAC International, 85(6), 1217-1240. https://doi.org/10.1093/jaoac/85.6.1217 
Miron, J., Zuckerman, E., Sadeh, D., Adin, G., Nikbachat, M., Yosef, E., Ben-Ghedalia, D., Carmi, A., Kipnis, T., \& Solomon, R. (2005). Yield, composition and in vitro digestibility of new forage sorghum varieties and their ensilage characteristics. Animal Feed Science and Technology, 120(1-2), 17-32. https://doi.org/10.1016/j.anifeedsci.2005.01.008

Moreira, A., Moraes, L. A. C., Schroth, G., \& Mandarino, J. M. G. (2015). Effect of nitrogen, row spacing, and plant density on yield, yield components, and plant physiology in soybean-wheat intercropping. Agronomy Journal, 107(6), 2162-2170. https://doi.org/10.2134/agronj15.0121

NRC. (2001). Requirements of Dairy Cattle Seventh Revised Edition, 2001. In N. R. Council (Ed.), National Academy Press, Washington D.C. (Seventh).

Palmonari, A., Gallo, A., Fustini, M., Canestrari, G., Masoero, F., Sniffen, C. J., \& Formigoni, A. (2016). Estimation of the indigestible fiber in different forage types. Journal of Animal Science, 94(1), 248-254. https://doi.org/10.2527/jas.2015-9649

Shaver, R. D., Lauer, J. G., Coors, J. G., \& Hoffman, P. C. (2006). Milk2006 Corn Silage: Calculates TDN-1x, NEl -3x, milk per ton, and milk per acre. Milk 2006corn silagev1.xls. Accessed on 17th July, 2021 on website: http: //www .uwex .edu/ ces/dairynutrition/ spreadsheets .cfm. http: / / www .uwex .edu/ ces/ dairynutrition/ spreadsheets .cfm.\%0AStone,

Shoemaker, C. E., \& Bransby, D. I. (2010). The role of sorghum as a bioenergy feedstocked. In R. Braun (Ed.), Sustainable Alternative Fuel Feedstock Opportunities, Challenges and Roadmaps for Six US Regions (pp. 149-159). Soil and Water Conservation Society.

Snider, J. L., Raper, R. L., \& Schwab, E. B. (2012). The effect of row spacing and seeding rate on biomass production and plant stand characteristics of nonirrigated photoperiod-sensitive sorghum (Sorghum bicolor (L.) Moench). Industrial Crops and Products, 37(1), 527-535. https://doi.org/10.1016/j.indcrop.2011.07.032

Sniffen, C. J., O’Connor, J. D., Van Soest, P. J., Fox, D. G., \& Russell, J. B. (1992). A net carbohydrate and protein system for evaluating cattle diets: II. Carbohydrate and protein availability. Journal of Animal Science, 70(11), 3562-3577. https://doi.org/10.2527/1992.70113562x

Staggenborg, S. A., Dhuyvetter, K. C., \& Gordon, W. B. (2008). Grain sorghum and corn comparisons: Yield, economic, and environmental responses. Agronomy Journal, 100(6), 1600-1604. https://doi.org/10.2134/agronj2008.0129

Steiner, J. L. (1986). Dryland grain sorghum water use, light interception, and growth responses to planting geometry. Agronomy Journal, 78(4), 720-726. https://doi.org/10.2134/agronj1986.00021962007800040032x

Stickler, F. C., \& Laude, H. H. (1960). Effect of Row Spacing and Plant Population on Performance of Corn, Grain Sorghum and Forage Sorghum 1 . Agronomy Journal, 52(5), 275-277. https://doi.org/10.2134/agronj1960.00021962005200050011x

Tang, C., Yang, X., Chen, X., Ameen, A., \& Xie, G. (2018). Sorghum biomass and quality and soil nitrogen balance response to nitrogen rate on semiarid marginal land. Field Crops Research, 215(2), 12-22. https://doi.org/10.1016/j.fcr.2017.09.031

Tilley, J. M. A., \& Terry, R. A. (1963). A two-stage technique for the in vitro digestion of forage crops. Grass and Forage Science, 18(2), 104-111. https://doi.org/10.1111/j.1365-2494.1963.tb00335.x

Van Soest, P. J., Robertson, J. B., \& Lewis, B. A. (1991). Methods for Dietary Fiber, Neutral Detergent Fiber, and Nonstarch Polysaccharides in Relation to Animal Nutrition. Journal of Dairy Science, 74(10), 3583-3597. https://doi.org/10.3168/jds.S0022-0302(91)78551-2

Yin, R. K. (2015). O estudo de Caso (5th ed.). Bookman.

Yu, K. M. J., McKinley, B., Rooney, W. L., \& Mullet, J. E. (2021). High planting density induces the expression of GA3-oxidase in leaves and GA mediated stem elongation in bioenergy sorghum. Scientific Reports, 11(1), 1-13. https://doi.org/10.1038/s41598-020-79975-8 